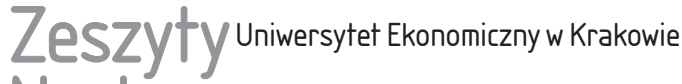 Naukowe
}

$6(966)$

ISSN 1898-6447

Zesz. Nauk. UEK, 2017; 6(966): 59-77 DOI: 10.15678/ZNUEK.2017.0966.0604

\section{Realizacja celów polityki klimatyczno-energetycznej Unii Europejskiej w kontekście polityki energetycznej w wybranych państwach członkowskich}

\section{Streszczenie}

W artykule przedstawiono wyniki analizy realizacji celów polityki klimatyczno-energetycznej Unii Europejskiej w wybranych państwach członkowskich w kontekście prowadzonej przez te państwa własnej polityki energetycznej. Przyjęty okres analizy obejmuje lata 2008-2014. Do analizy wybrano siedem krajów Unii Europejskiej: Czechy, Danię, Niemcy, Francję, Litwę, Polskę oraz Wielką Brytanię. Realizacja poszczególnych celów polityki klimatyczno-energetycznej Unii Europejskiej przebiega w wybranych krajach w różnym zakresie. Przeprowadzone badania pozwalają na wyciągnięcie wniosku, że coraz więcej państw prowadzi politykę energetyczną, opierając się przede wszystkim na polityce krajowej, która nie zawsze jest spójna z założeniami pakietu klimatyczno-energetycznego Unii Europejskiej.

Magdalena Zajączkowska, Uniwersytet Ekonomiczny w Krakowie, Wydział Ekonomii i Stosunków Międzynarodowych, Katedra Europejskiej Integracji Gospodarczej, ul. Rakowicka 27, 31-510 Kraków, e-mail: zajaczkm@uek.krakow.pl

* Artykuł powstał w wyniku realizacji projektu badawczego finansowanego ze środków przyznanych Wydziałowi Ekonomii i Stosunków Międzynarodowych Uniwersytetu Ekonomicznego w Krakowie w ramach dotacji na utrzymanie potencjału badawczego. 
Słowa kluczowe: cele polityki klimatyczno-energetycznej, efektywność energetyczna, emisja gazów cieplarnianych, odnawialne źródła energii, polityka klimatyczno-energetyczna Unii Europejskiej.

Klasyfikacja JEL: A11, E61, F50, H89.

\section{Wprowadzenie}

Polityka klimatyczno-energetyczna Unii Europejskiej powstawała w odpowiedzi na sytuacje konfliktowe i kryzysowe w sektorze energii, pojawiające się zarówno w państwach członkowskich ugrupowania, jak i na świecie. Z uwagi na zmieniające się okoliczności i zachodzące procesy była następnie uzupełniana przez liczne strategie i działania. Koncentrują się one na zagwarantowaniu bezpieczeństwa dostaw, wzroście konkurencyjności oraz zrównoważonym rozwoju. Ponadto działaniom podejmowanym na szczeblu Unii Europejskiej towarzyszą przedsięwzięcia w zakresie ochrony środowiska, a przede wszystkim przeciwdziałanie jego degradacji.

Obecnie wyznaczone cele polityki klimatyczno-energetycznej Unii Europejskiej powinny zostać osiągnięte do 2020, 2030 i 2050 r. Dotyczą one dalszej redukcji emisji gazów cieplarnianych, zwiększenia udziału energii ze źródeł odnawialnych, poprawy efektywności energetycznej oraz zwiększenia udziału energii w połączeniach międzysystemowych. Podejmowane działania wpisują się w postanowienia międzynarodowego porozumienia klimatycznego, zawartego na szczycie COP21 w Paryżu w 2015 r. Pomimo przyjęcia wspólnej strategii energetycznej przez wszystkie państwa członkowskie w postaci kolejnego pakietu klimatyczno-energetycznego UE, budzi ona liczne kontrowersje i stwarza problemy związane z jej realizacją. Spowodowane jest to przede wszystkim rozbieżnościami interesów społeczno-gospodarczych poszczególnych państw członkowskich. Powoduje to, że państwa te prowadzą politykę energetyczną opartą na polityce krajowej, co czyni próbę osiągnięcia konsensusu często niemożliwą.

Głównym celem artykułu jest przedstawienie wyników analizy realizacji celów polityki klimatyczno-energetycznej Unii Europejskiej w wybranych państwach członkowskich w kontekście prowadzonej przez te państwa własnej polityki energetycznej. Do celów szczegółowych zaliczono: przedstawienie zmian w poziomie zależności energetycznej wybranych państw członkowskich Unii, prezentację podstaw krajowych założeń polityki energetycznej tych państw oraz odpowiedź na pytanie, czy działania podejmowane przez wybrane państwa członkowskie w zakresie krajowej polityki energetycznej korespondują z realizacją celów przyjętej przez Unię Europejską polityki klimatyczno-energetycznej.

Wstępna analiza wymienionych zagadnień pozwala postawić tezę, że działania podejmowane przez wybrane państwa członkowskie w zakresie krajowej polityki 
energetycznej stoją w sprzeczności z osiągnięciem celów polityki klimatyczno-energetycznej Unii Europejskiej.

Badania nad zagadnieniem realizacji polityki klimatyczno-energetycznej Unii Europejskiej odnoszą się do każdego jej aspektu. W głównym nurcie prowadzone są przede wszystkim badania dotyczące wykorzystania poszczególnych paliw w miksach energetycznych wybranych państw (np. [McCombie i Jefferson 2016, Belyi 2016]). Szeroko analizowane są również strategie energetyczne poszczególnych państw. Badania te dotyczą modelowania systemów energetycznych [Kamiński 2010, Popławski 2012], modeli optymalnych miksów energetycznych [Gołębiowski i in. 2013], zmiany struktury źródeł energii [Kaliski, Frączek i Szurlej 2011, Olkuski 2014] czy szeroko rozumianej doktryny energetycznej [Kasztelewicz 2014, Szczerbowski 2015] oraz roli wykorzystania poszczególnych surowców energetycznych we wzroście gospodarczym kraju [Gurgul i Lach 2011]. Przegląd prowadzonych badań prowadzi do wniosku, że zagadnienie polityki klimatyczno-energetycznej jest rozpatrywane nie tylko z punktu widzenia ekonomicznego czy politycznego, ale również socjologicznego [Badera i Kocoń 2014]. Podejmuje się także badania dotyczące problematyki bezpieczeństwa energetycznego z uwzględnieniem procesu supranacjonalizacji [Riedel 2010]. Niniejsza praca łączy zagadnienia realizacji celów polityki klimatyczno-energetycznej Unii Europejskiej z założeniami polityki energetycznej prowadzonej w wybranych państwach i próbą uwzględnienia w analizie interesów społeczno-ekonomicznych tych państw.

Przyjęty okres analizy obejmuje lata 2008-2014. Początek analizy został wybrany z uwagi na wprowadzenie w 2008 r. pakietu klimatyczno-energetycznego w Unii Europejskiej, który miał stanowić pierwszą próbę kompleksowego określenia celów i założeń tej polityki. Realizacja celów została oparta na analizie literatury przedmiotu, aktów prawnych, dokumentów instytucji UE oraz badaniach przeprowadzonych w ramach projektu Odysse-Mure Komisji Europejskiej. Wykorzystano następujące metody badawcze: analizę krytyczną literatury przedmiotu, metodę statystyczną (na podstawie danych Eurostatu, projektu Odysse-Mure Komisji Europejskiej i indeksu efektywności energetycznej ODEX) i porównawczą. Do analizy wybrano siedem krajów Unii Europejskiej: Czechy, Danię, Niemcy, Francję, Litwę, Polskę oraz Wielką Brytanię. Kryterium wyboru krajów oparto na wskaźniku zależności energetycznej, zmianach, jakie nastąpiły w tym zakresie od 2008 r., oraz poziomie samodzielności w kreowaniu krajowej polityki energetycznej. Francja została wyłączona z analizy zmian w zakresie efektywności energetycznej z uwagi na brak danych i raportów. 


\section{Cele polityki klimatyczno-energetycznej Unii Europejskiej}

Pakietem klimatyczno-energetycznym określa się zbiór sześciu aktów przyjętych przez Komisję Europejską w 2007 i 2008 r. Jest to początek tworzenia w pełni kompleksowej strategii działania Unii Europejskiej w zakresie polityki energetycznej i klimatycznej. W przedstawionych dokumentach starano się w jak najszerszym zakresie uwzględnić pożądane kierunki i cele konieczne do osiągnięcia zarówno przez Unię Europejską, jak i państwa członkowskie. W jednym z dokumentów, Europejskiej polityce energetycznej [Europejska polityka... 2007], określono podstawowe założenia polityki klimatyczno-energetycznej, tj.: przeciwdziałanie zmianom klimatycznym, ograniczanie podatności Unii na wpływ czynników zewnętrznych wynikającej z zależności od importu paliw oraz wspieranie zatrudnienia i wzrostu gospodarczego, co zapewni odbiorcom bezpieczeństwo zaopatrzenia w energię po przystępnych cenach.

Pakiet klimatyczno-energetyczny uwzględnia następujące cele (pakiet $3 \times 20 \%$ ):

- zmniejszenie emisji gazów cieplarnianych przynajmniej o 20\% do 2020 r. w porównaniu z rokiem bazowym 1990 i zmniejszenie o 30\% emisji gazów cieplarnianych do 2020 r. w UE w przypadku, gdyby uzyskano światowe porozumienie co do redukcji emisji gazów cieplarnianych,

- zwiększenie udziału energii ze źródeł odnawialnych w zużyciu energii końcowej do $20 \%$ do 2020 r., w tym 10\% udziału biopaliw w zużyciu paliw,

- zwiększenie efektywności wykorzystania energii o 20\% do 2020 r. w porównaniu z prognozą zapotrzebowania na paliwa i energię.

W 2014 r. przyjęto ramy nowej europejskiej polityki energetycznej oparte na pakiecie klimatyczno-energetycznym Unii Europejskiej do 2020 r. Ustalono, że do 2030 r. w zakresie klimatu i energii realizowane będą trzy główne cele [Szafrański 2014, s. 141]:

1) ograniczenie emisji gazów cieplarnianych o co najmniej $40 \%$ w stosunku do poziomu z 1990 r., co stanowi podwojenie wymaganego poziomu określonego w celu wyznaczonym do realizacji do $2020 \mathrm{r}$.,

2) zagwarantowanie co najmniej 27-procentowego udziału energii ze źródeł odnawialnych w ogólnym bilansie energetycznym, co stanowi wzrost wymaganego udziału o 7 punktów procentowych (p.p.) w stosunku do wcześniej obowiązującego,

3) wzrost efektywności energetycznej o co najmniej $27 \%$, co również stanowi podniesienie wymagań o 7 p.p. w stosunku do celu wyznaczonego na 2020 r.

Państwa członkowskie zostały zobowiązane do zrealizowania wymienionych celów, pozostawiono im jednak swobodę w zakresie ustalania ewentualnie wyższych poziomów celów krajowych. 
Ustalono ponadto, że do 2050 r. globalne emisje gazów cieplarnianych powinny zostać zredukowane maksymalnie o $80 \% \mathrm{w}$ stosunku do poziomu z 1990 r., co oznacza, że kraje uprzemysłowione powinny do 2050 r. zredukować emisje o 60-80\%. Kluczowymi etapami w realizacji tego celu ma być osiągnięcie 40-procentowej redukcji emisji do 2030 r. i 60-procentowej redukcji emisji do 2040 r. przez [Szafrański 2014, s. 142-143]:

- ograniczenie emisji o 43\% (w stosunku do poziomu z 2005 r.) przez sektory, które objęte są unijnym systemem handlu uprawnieniami do emisji (ETS), w wyniku czego należy doprowadzić do podjęcia reform mających na celu wzmocnienie pozycji ETS,

- ograniczenie emisji o 30\% (w stosunku do poziomu z 2005 r.) przez sektory, które nie są objęte unijnym systemem handlu uprawnieniami do emisji, co wymaga ustalenia szczegółowych planów dla poszczególnych krajów członkowskich.

\section{Zależność energetyczna krajów Unii Europejskiej}

Zależność UE-28 od importu energii zwiększyła się z ok. 40\% zużycia energii brutto w latach 80. XX w. do 53,5\% w 2014 r.; w 2008 r. wynosiła aż 54,7\%. Najwyższe wskaźniki zależności energetycznej odnotowano w przypadku ropy naftowej $(88,4 \%)$ i gazu ziemnego (65,3\%). W latach 2003-2013 zależność Unii Europejskiej od dostaw z państw nienależących do UE rosła szybciej w przypadku gazu ziemnego (o 13,3 p.p.) niż w przypadku ropy naftowej (o 9,9 p.p.) i paliw stałych (9,2 p.p.). Od 2004 r. import netto energii do UE-28 jest większy niż jej produkcja pierwotna; innymi słowy, import netto pokrywa ponad połowę krajowego zużycia energii brutto w UE-28 [Energy Production... 2016, s. 1].

Na rys. 1 przedstawiono poziom zależności energetycznej krajów Unii Europejskiej w 2014 r. Z zaprezentowanych na rysunku danych wynika, że w 2014 r. kraje Unii Europejskiej były uzależnione od importu surowców energetycznych i energii w ponad 53\%. Największe uzależnienie energetyczne odnotowano w przypadku Malty $(97,7 \%)$, Luksemburga $(96,6 \%)$ oraz Cypru $(93,4 \%)$, co oznacza, że kraje te były prawie całkowicie zależne od importu energii pierwotnej. W najmniejszym stopniu uzależnione były Estonia (8,9\%), Dania (12\%) oraz Rumunia (17\%). Również sytuacja Polski była korzystna, zależność energetyczna wynosiła 28,6\%, co pozwala na zakwalifikowanie naszego kraju do czołówki najbardziej bezpiecznych energetycznie państw.

Należy odnotować znaczne uzależnienie od importu surowców i energii największych unijnych gospodarek. W przypadku Włoch wynosi ono 75,9\%, Niemiec $61,6 \%$, Francji 46,1\% oraz Wielkiej Brytanii 45,5\%. Jedynie w przypadku Francji i Wielkiej Brytanii jest to poziom poniżej średniej unijnej. Są to ponadto kraje 
tzw. starej Unii Europejskiej, które od kilkudziesięciu lat aktywnie uczestniczą w tworzeniu i realizacji unijnej polityki klimatyczno-energetycznej, której jednym z podstawowych celów jest zagwarantowanie bezpieczeństwa energetycznego krajom ugrupowania, co rodzi dodatkowe pytania o skuteczność wprowadzanych na szczeblu unijnym rozwiązań.

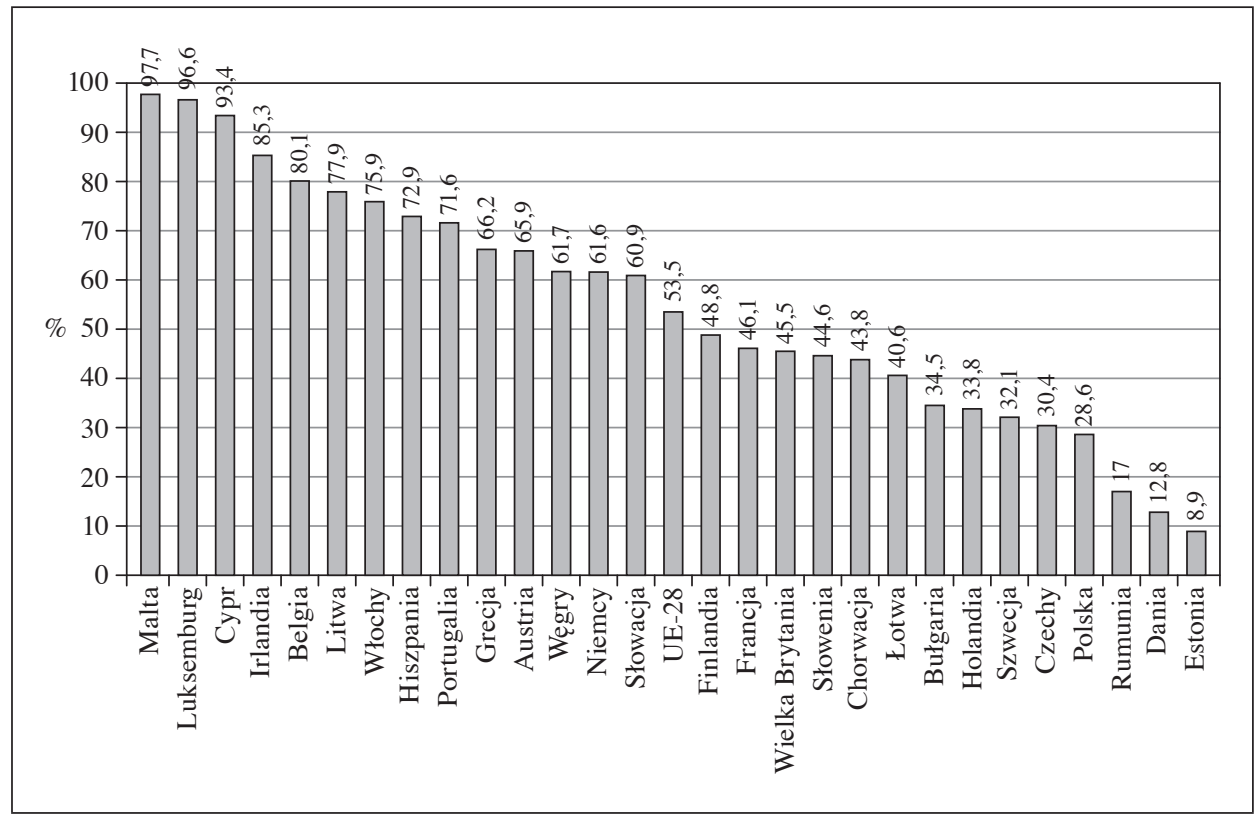

Rys. 1. Poziom zależności energetycznej krajów Unii Europejskiej w 2014 r. Źródło: opracowanie własne na podstawie [Energy Dependency 2016].

Powyższe rozważania uzupełniono o analizę zmian w poziomie zależności energetycznej krajów Unii Europejskiej między 2008 r., jako początkowym okresem wprowadzania pakietu klimatyczno-energetycznego Unii Europejskiej, a 2014 r. (rys. 2).

Od czasu wprowadzenia pakietu klimatyczno-energetycznego Unii Europejskiej największa zmiana w poziomie zależności energetycznej miała miejsce w Danii (33,3 p.p.), na Litwie (20,1 p.p.), w Wielkiej Brytanii (19,3 p.p.), w Czechach $(2,4$ p.p.) oraz w Niemczech ( 0,8 p.p.). Są to kraje, w których nastąpił wzrost uzależnienia energetycznego od 2008 r. Do krajów, w których nastąpiła poprawa sytuacji energetycznej w zakresie importu surowców i energii, należy zaliczyć: Łotwę (18,2 p.p.), Bułgarię (17,2 p.p.), Estonię (15,8 p.p.) i Portugalię (11,8 p.p.). 


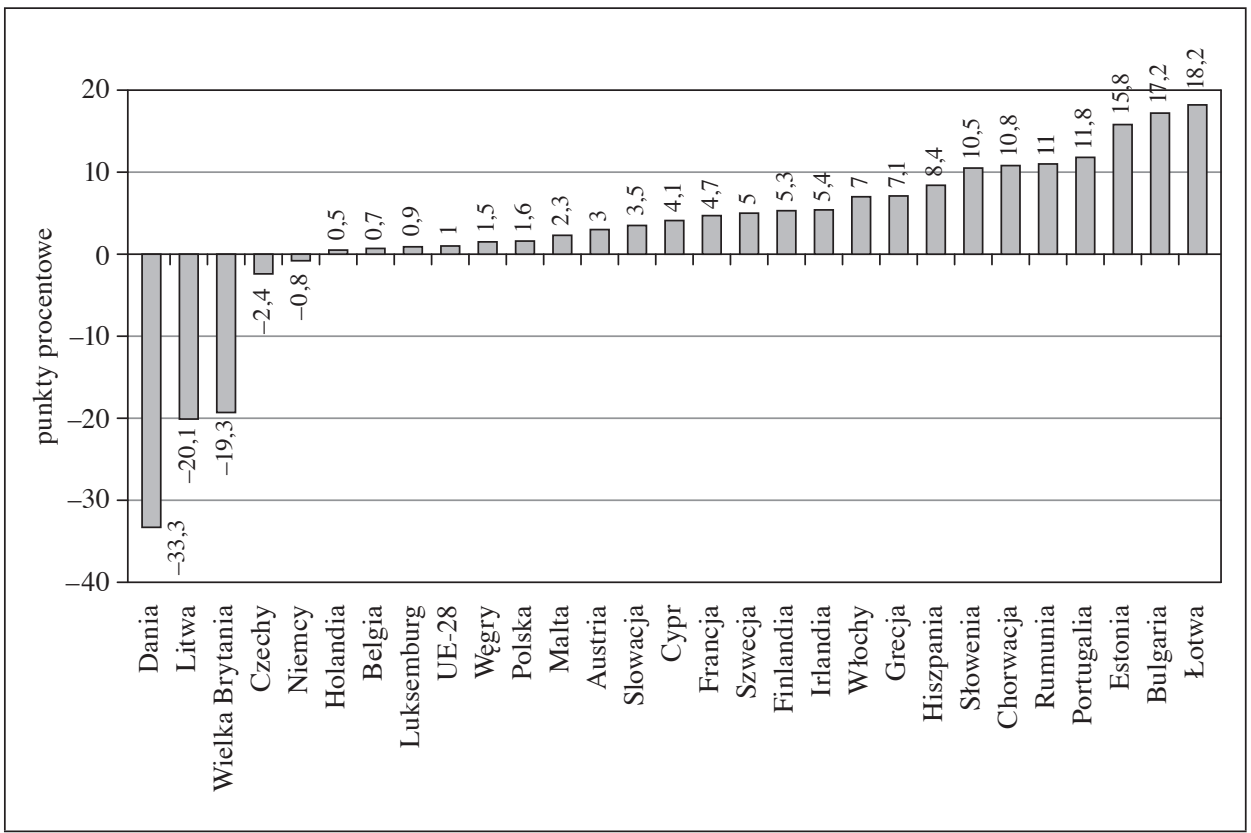

Rys. 2. Zmiana w poziomie zależności energetycznej krajów Unii Europejskiej od 2008 do 2014 r.

Źródło: opracowanie własne na podstawie [Energy Dependency 2016].

Biorąc pod uwagę poziom zależności energetycznej poszczególnych krajów, zmiany, jakie nastąpiły w tym zakresie od 2008 r., oraz poziom samodzielności w kreowaniu krajowej polityki energetycznej, ostatecznie do analizy ilościowej wybrano siedem krajów Unii Europejskiej: Czechy, Danię, Niemcy, Francję, Litwę, Polskę oraz Wielką Brytanię. Każdy z tych krajów podejmuje działania kreujące własną politykę energetyczną i jednocześnie ze względu na swoją rolę w Unii Europejskiej aktywnie wpływa na kształt polityki klimatyczno-energetycznej UE. W Polsce dominuje, jedno z najwyższych w Unii Europejskiej, wykorzystanie paliw kopalnych. W Czechach, pomimo znacznego udziału źródeł kopalnych w bilansie energetycznym, następuje rozwój energetyki jądrowej. W przypadku Niemiec i Danii istotną rolę odgrywa rozwój energetyki odnawialnej. We Francji wykorzystywana jest głównie energia jądrowa, od której w ostatnich latach odeszła całkowicie Litwa. W Wielkiej Brytanii natomiast zadecydowano o dywersyfikacji źródeł energetycznych i rozwoju każdego z nich. 


\section{Realizacja celów polityki klimatyczno-energetycznej Unii Europejskiej w wybranych państwach członkowskich}

Pierwszy cel ilościowy polityki klimatyczno-energetycznej Unii Europejskiej dotyczy zmniejszenia emisji gazów cieplarnianych przynajmniej o $20 \%$ do $2020 \mathrm{r}$. w porównaniu z rokiem bazowym 1990 oraz ewentualnego dalszego obniżenia o 30\% emisji gazów cieplarnianych do 2020 r. w UE w przypadku, gdyby uzyskano światowe porozumienie co do redukcji emisji gazów cieplarnianych.

Na rys. 3 przedstawiono poziomy emisji gazów cieplarnianych w wybranych państwach Unii Europejskiej (Czechy, Dania, Francja, Litwa, Niemcy, Polska, Wielka Brytania) z uwzględnieniem średniej unijnej w 2008 i 2014 r. w stosunku do 1990 r., jako roku bazowego, oraz z uwzględnieniem unijnego celu wyznaczonego do osiągnięcia na $2020 \mathrm{r}$. W analizie uwzględniono również dodatkowe zobowiązania wynikające z porozumienia podpisanego w Paryżu w 2015 r.

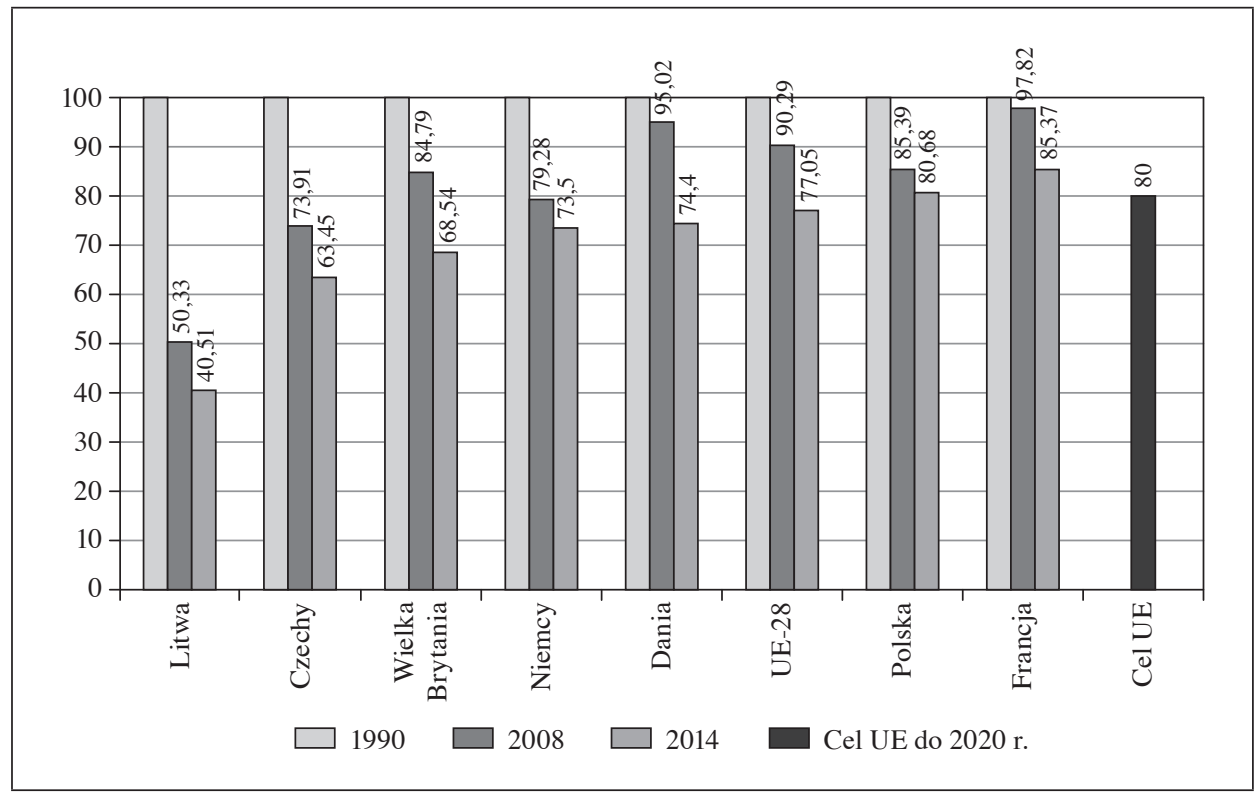

Rys. 3. Emisja gazów cieplarnianych w wybranych państwach Unii Europejskiej w latach 2008 i $2014\left(1990=100 ; \mathrm{CO}_{2} \mathrm{e}\right)$

Źródło: opracowanie własne na podstawie [Greenhouse Gas Emissions 2016].

W 2014 r. najniższy poziom emisji $\mathrm{CO}_{2}$ odnotowano na Litwie, najwyższy natomiast we Francji. Większość z analizowanych krajów (Litwa, Czechy, Wielka Brytania, Niemcy oraz Dania) osiągnęła poziom niższy niż średnia unijna i niższy 
niż wyznaczony na poziomie 20\% cel. Największe zmiany między 2008 a 2014 r. odnotowano w Danii (20,62 p.p.) oraz w Wielkiej Brytanii (16,25 p.p.), a najmniejsze w Polsce (4,71 p.p.) oraz w Niemczech (5,78 p.p.). Pomimo że większość wybranych krajów osiągnęła określony na poziomie $20 \%$ cel unijny, konieczne jest podejmowanie dalszych działań zmierzających do redukcji emisji gazów cieplarnianych z uwagi na zobowiązania wynikające z porozumienia międzynarodowego zawartego w Paryżu w 2015 r.), zakładającego 30-procentową redukcję emisji.

Drugi cel polityki klimatyczno-energetycznej Unii Europejskiej dotyczy zwiększenia udziału energii ze źródeł odnawialnych w zużyciu energii końcowej do $20 \%$ do 2020 r., w tym $10 \%$ udziału biopaliw w zużyciu paliw.

Na rys. 4 przedstawiono udział energii ze źródeł odnawialnych w zużyciu energii końcowej brutto w wybranych do analizy państwach Unii Europejskiej w 2008 i 2014 r., z uwzględnieniem celów krajowych i celu unijnego wyznaczonego do osiągnięcia na $2020 \mathrm{r}$.

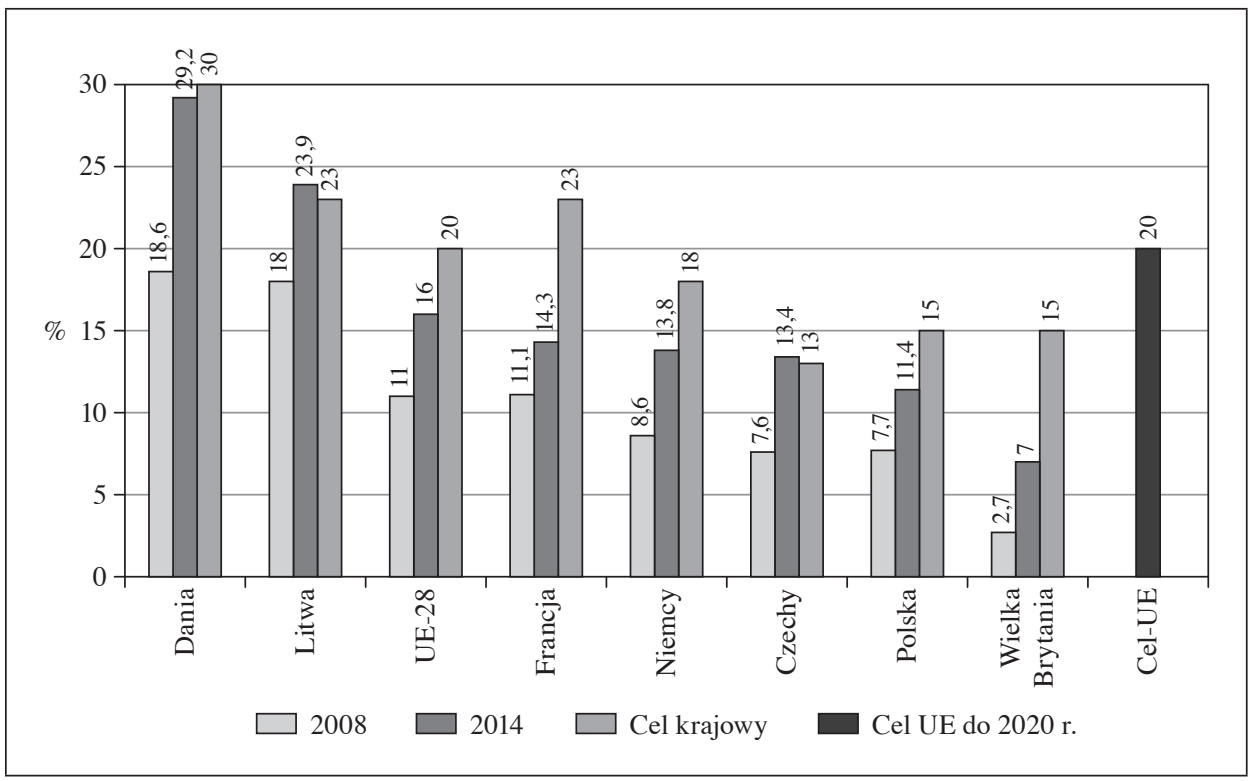

Rys. 4. Udział energii odnawialnej w zużyciu energii końcowej brutto w wybranych państwach Unii Europejskiej w latach 2008 i 2014

Źródło: opracowanie własne na podstawie [Share of Renewable Energy... 2016].

W 2014 r. największy udział energii pochodzącej ze źródeł odnawialnych odnotowano w Danii $(29,2 \%)$ oraz na Litwie $(23,9 \%)$. W krajach tych udział energii pochodzącej z tych źródeł przekraczał poziom średniej unijnej. Tylko Litwa i Czechy $(13,4 \%)$ przekroczyły już w 2014 r. poziom określony w celu krajowym wyznaczony 
do osiągnięcia na 2020 r. Najdalej od osiągnięcia wyznaczonego celu krajowego jest Francja ( 8,7 p.p.) oraz Wielka Brytania (8 p.p.). Polska jest bliska osiągnięcia celu krajowego, który został wyznaczony na poziomie 15\%; w 2014 r. udział energii pochodzącej ze źródeł odnawialnych w bilansie energetycznym kraju wynosił 11,4\%.

Trzeci cel polityki klimatyczno-energetycznej Unii Europejskiej związany jest ze zwiększeniem efektywności wykorzystania energii o $20 \%$ do $2020 \mathrm{r}$. w stosunku do prognozy zapotrzebowania na paliwa i energię. Efektywność mierzona jest dwoma wskaźnikami: zużyciem energii pierwotnej oraz zużyciem energii finalnej. Mając na uwadze tak określony cel, należy w Unii Europejskiej podjąć działania, które doprowadzą do wykorzystywania energii pierwotnej na poziomie 1483 Mtoe w 2020 r. oraz energii finalnej na poziomie 1086 Mtoe w $2020 \mathrm{r}$.

W latach 2008-2014 zużycie energii pierwotnej w Unii Europejskiej zmniejszyło się o 186 Mtoe (a więc o 10,9\%), do poziomu 1507,1 Mtoe. Był to najniższy poziom w ostatniej dekadzie i niższy niż zużycie energii w 1990 r. (1569,4 Mtoe) [Primary Energy... 2016, s. 1].

Zmiany w zużyciu energii finalnej w Unii Europejskiej odzwierciedlają zmiany w zużyciu energii pierwotnej, ale na niższym poziomie. W 2014 r. zużycie energii finalnej zmniejszyło się o 119 Mtoe (10\%) w stosunku do poziomu z 2008 r., i wynosiło 1061,2 Mtoe. Był to najniższy poziom konsumpcji energii od $1994 \mathrm{r}$. Najwyższe zużycie energii finalnej miało miejsce w 2006 r. i wynosiło 1190 Mtoe [Final Energy... 2016, s. 1].

Przeprowadzone badania pokazują, że w latach 2000-2013 efektywność energetyczna w Unii Europejskiej wzrosła o 15\% (spadek zużycia energii o ok. 10\%). Od czasu wystąpienia kryzysu w 2008 r. odnotowano niewielkie spowolnienie tempa poprawy efektywności energetycznej - roczny 1-procentowy wzrost w porównaniu ze średnim rocznym 1,3-procentowym wzrostem między 2000 a 2007 r. Około 33\% oszczędności w zużyciu energii odnotowano w sektorze gospodarstw domowych, $32 \% \mathrm{w}$ przemyśle, $27 \% \mathrm{w}$ sektorze transportowym oraz $8 \%$ w usługach [Odyssee-Mure 2015g, s. 5].

Największa poprawa efektywności energetycznej w Unii Europejskiej nastąpiła w sektorze gospodarstw domowych, ponieważ został osiągnięty cel w zakresie poprawy efektywności wykorzystania energii, wyznaczony na poziomie 1,7\% rocznie. W latach 2000-2013 nastąpiła poprawa efektywności energetycznej w omawianym sektorze o $21 \%$. Od 2000 r. uzyskano 20-procentową poprawę w zakresie systemu ogrzewania, 15-procentową poprawę w zakresie podgrzewania wody oraz 14-procentową poprawę w przypadku stosowanych urządzeń elektrycznych. Od 2008 r. nastąpiło spowolnienie tempa poprawy efektywności energetycznej w sektorze gospodarstw domowych i wyniosło średnio 1,3\% dla całej UE [Odyssee-Mure 2015h, s. 49-50]. 
W Czechach również nastąpiła poprawa efektywności energetycznej w sektorze gospodarstw domowych. Zmniejszyła się konsumpcja energii grzewczej i elektrycznej, głównie w wyniku poprawy efektywności energetycznej budynków, wykorzystania bardziej zaawansowanych technicznie i technologicznie urządzeń gospodarstwa domowego, jak też wzrostu cen energii. W okresie 2000-2012 tempo poprawy efektywności energetycznej w Czechach było wyższe o 3,2 p.p. niż średnia unijna (18,7\%) [Odyssee-Mure 2015a, s. 1].

Niższe tempo poprawy efektywności energetycznej w sektorze gospodarstw domowych odnotowano w Danii. W okresie 2000-2012 nastąpiła 15-procentowa poprawa (tempo roczne wynosiło średnio 1,3\%). Największa poprawa efektywności energetycznej nastąpiła w przypadku ogrzewania budynków (19\%), dzięki wymianie starych instalacji grzewczych na nowe oparte na spalaniu gazu oraz wycofywaniu instalacji grzewczych wykorzystujących energię elektryczną [Odyssee-Mure 2015b, s. 1].

Podobne zmiany odnotowano w Niemczech - w latach 2000-2012 roczne tempo poprawy efektywności energetycznej w sektorze gospodarstw domowych wynosiło $1,7 \%$. Największa poprawa efektywności nastąpiła również dzięki zmianom metod ogrzewania pomieszczeń i wykorzystaniu energooszczędnych artykułów gospodarstwa domowego [Odyssee-Mure 2015c, s. 1].

$\mathrm{Na}$ Litwie konsumpcja energii w sektorze gospodarstw domowych odpowiada za 32\% konsumpcji energii finalnej. Stąd zmiany w zakresie poprawy efektywności energetycznej są w tym sektorze szczególnie istotne. Od 2000 r. nastąpiła poprawa efektywności energetycznej o $6 \%$ dzięki remontom starych wielopokoleniowych domów oraz budynków publicznych [Odyssee-Mure 2015d, s. 1].

W Polsce w latach 2000-2004 również odnotowano znaczny wzrost efektywności energetycznej w sektorze gospodarstw domowych (indeks ODEX obniżył się z poziomu 100 punktów w 2000 r. do poziomu 78 punktów w 2004 r.). Od 2004 r. nastąpiło spowolnienie tempa wzrostu efektywności energetycznej w omawianym sektorze. W 2013 r. indeks ODEX wynosił dla tego sektora 76 punktów. Problem ze zwiększeniem efektywności energetycznej dotyczył przede wszystkim ogrzewania pomieszczeń [Odyssee-Mure 2015e, s. 2].

Jeden z największych wzrostów poprawy efektywności energetycznej w sektorze gospodarstw domowych w okresie 2000-2012 odnotowano w Wielkiej Brytanii - ok. 22\% (średnie roczne tempo 4\%). Wynikało to głównie z poprawy izolacji budynków i unowocześnienia systemów grzewczych [Odyssee-Mure 2015f, s. 1].

Analiza celów wyznaczonych dla sektora przemysłowego w Unii Europejskiej została podzielona na dwa okresy. W poszczególnych latach między 2000 a $2007 \mathrm{r}$. konsumpcja energii w przemyśle utrzymywała się na zbliżonym poziomie. Od czasu wystąpienia kryzysu nastąpił gwałtowny spadek konsumpcji energii w przemyśle i był on dwukrotnie szybszy niż spadek aktywności podmiotów 
gospodarczych w tym sektorze. Od 2007 r. spowolnienie tempa poprawy efektywności energetycznej w omawianym sektorze ( $0,9 \%$ w porównaniu z $1,9 \%$ w okresie 2000-2007) było spowodowane zmianami w niektórych branżach na skutek wystąpienia kryzysu gospodarczego, zwłaszcza w przemyśle metalurgicznym, cementowym oraz maszynowym [Odyssee-Mure 2015i, s. 27, 29].

W okresie 2000-2013 w Czechach nastąpiła poprawa efektywności energetycznej o 19,1\%. Największe zmiany odnotowano w przemyśle stalowym, chemicznym i papierniczym [Odyssee-Mure 2015a, s. 1].

W Danii również odnotowano w latach 2000-2012 poprawę efektywności energetycznej w przemyśle o ok. $16 \%$ (średnio o 1,5\% rocznie). Największe zmiany zaobserwowano w sektorze papierniczym (poprawa o ok. 52\%) oraz chemicznym (poprawa o ok. 44\%) [Odyssee-Mure 2015b, s. 1].

Najmniejsze zmiany zaobserwowano w omawianym sektorze w Niemczech - średnioroczne tempo wyniosło ok. 1,3\% i odpowiadało poziomowi zaobserwowanemu dla całej gospodarki. Największe zmiany miały miejsce w sektorze stalowym, papierniczym i chemicznym [Odyssee-Mure 2015c, s. 1].

Na Litwie odnotowano największy wzrost tempa poprawy efektywności energetycznej w przemyśle spośród wybranych krajów. W okresie 2000-2012 wynosił on $40 \%$. Warto wspomnieć, że konsumpcja energii finalnej w tym kraju w przemyśle odpowiada tylko za $20 \%$ konsumpcji energii finalnej dla całego kraju. Największą poprawę (o 20\%) odnotowano w sektorze chemicznym, który odpowiada za $30 \%$ konsumpcji energii pierwotnej w przemyśle [Odyssee-Mure 2015d, s. 1].

W Polsce w latach 2000-2013 również nastąpił wzrost efektywności energetycznej w przemyśle (indeks ODEX obniżył się z poziomu 100 punktów w 2000 r. do poziomu poniżej 51 punktów w 2013 r.). Poprawę zaobserwowano we wszystkich gałęziach przemysłu, choć szczególne działania zostały poczynione w przemyśle papierniczym, stalowym i chemicznym (podobnie jak w Czechach). Sektory te odpowiadały w $40 \%$ za wzrost efektywności energetycznej w przemyśle [Odyssee-Mure 2015e, s. 2].

W ostatnim z omawianych krajów, Wielkiej Brytanii, w okresie 2000-2013 także odnotowano poprawę efektywności energetycznej - o ok. 26\%, zwłaszcza w sektorze chemicznym, gdzie nastąpiła poprawa o ok. 50\% [Odyssee-Mure 2015f, s. 1].

W sektorze transportowym natomiast wzrost efektywności energetycznej w Unii Europejskiej był stabilny i utrzymywał się w latach 2007-2013 na średniorocznym poziomie $1,2 \%$. Większy wzrost miał miejsce w sektorze samochodowym oraz w lotnictwie niż w branży przewozu towarów [Odyssee-Mure 2015j, s. 36].

W sektorze transportowym w Czechach w okresie 2000-2013 odnotowano poprawę efektywności energetycznej na poziomie 7,8\% (poziom niższy o 6,3 p.p. od średniej dla UE-28). Niewielkie zmiany w tym sektorze spowodowane były przede wszystkim budową sieci nowych dróg, brakiem kampanii i wsparcia na 
rzecz korzystania z komunikacji publicznej oraz zwiększeniem importu używanych samochodów z krajów Europy Zachodniej [Odyssee-Mure 2015a, s. 1].

Prawie dwa razy lepszy wynik odnotowano w Danii, gdzie w omawianym okresie nastąpiła poprawa efektywności energetycznej w transporcie o $13 \%$ [Odyssee-Mure 2015b, s. 1].

W Niemczech natomiast tempo poprawy efektywności energetycznej w transporcie $\mathrm{w}$ omawianym okresie było podobne jak w przemyśle (1,3\%). Najbardziej istotne zmiany nastąpiły w sektorze samochodowym ze względu na wprowadzanie coraz bardziej zaawansowanych technicznie i technologicznie wersji pojazdów [Odyssee-Mure 2015c, s. 1].

Najmniejszy postęp w poprawie efektywności energetycznej w transporcie odnotowano na Litwie - średnioroczne tempo w latach 2000-2012 wyniosło 0,5\%. Podstawową przyczyną tej sytuacji był wzrost zamożności obywateli, a przez to zwiększenie zakupów samochodów prywatnych, często o dużej mocy silnika [Odyssee-Mure 2015d, s. 1].

W latach 2000-2013 w Polsce odnotowano również wzrost efektywności energetycznej w transporcie (indeks ODEX obniżył się z poziomu 100 punktów w 2000 r. do poziomu 78 punktów w 2013 r., co oznacza roczny spadek średnio o 1,9\%). Wzrost efektywności energetycznej zaobserwowano przede wszystkim w sektorze samochodowym (6\%). W sektorze transportu towarów poprawa nastąpiła dopiero po 2005 r. - średnie tempo wzrostu efektywności energetycznej wynosiło 7,8\% [Odyssee-Mure 2015e, s. 2].

W Wielkiej Brytanii poprawa efektywności energetycznej w transporcie w omawianym okresie wyniosła ok. 15\%, głównie w wyniku poprawy technicznej i technologicznej wykorzystywanych samochodów [Odyssee-Mure 2015f, s. 1].

\section{Podstawowe założenia krajowej polityki energetycznej wybranych państw członkowskich Unii Europejskiej}

Polityka energetyczna Niemiec, określana jako Energiewende (transformacja energetyczna), została zainicjowana w 2012 r., w kilka miesięcy po awarii elektrowni w Fukushimie. Do najważniejszych założeń tej polityki należą [Szczerbowski 2015, s. 10]:

- wyłączenie z eksploatacji elektrowni atomowych do 2022 r.,

- znaczna redukcja emisji dwutlenku węgla,

- oparcie systemu elektroenergetycznego na odnawialnych źródłach energii.

Nowelizując ustawę przyjęto założenie, że udział energii odnawialnej w produkcji energii elektrycznej ma systematycznie wzrastać z obecnego poziomu ok. $20 \%$ do ok. $50 \%$ w 2030 r. i aż $80 \%$ w 2050 r. [Dena Ancillary... 2014]. 
Podkreśla się [Szczerbowski 2015, s. 10], że podstawowym problemem w realizacji nowej polityki energetycznej jest zapewnienie ciągłości dostaw energii po stopniowym wyłączaniu kolejnych elektrowni jądrowych. Zapewnienie ciągłości dostaw ma nastąpić z wykorzystaniem energetyki węglowej oraz gazu ziemnego, który jest surowcem niskoemisyjnym i pozwala na zachowanie celów redukcji emisji dwutlenku węgla. Pierwszą znaczącą zmianą związaną z nową koncepcją niemieckiej energetyki jest budowa nowych elektrowni zasilanych węglem. Takie działanie jest sprzeczne z celem polityki klimatyczno-energetycznej Unii Europejskiej, ale jest ono uzasadnione koniecznością zbilansowania wycofywanych mocy w elektrowniach jądrowych. Ponadto dotowanie rozwoju źródeł odnawialnych może prowadzić do obniżenia poziomu cen hurtowych energii elektrycznej poniżej progu opłacalności wytwarzania. Ocenia się, że zakres zmian w założeniach prowadzonej polityki energetycznej Niemiec jest jednym z najdalej idących w porównaniu z pozostałymi państwami członkowskmi UE.

Reforma sektora energetycznego Wielkiej Brytanii rozpoczęła się w 2012 r. Ocenia się, że w nowej polityce energetycznej Wielka Brytania odchodzi od modelu rynkowego w kierunku większej interwencji państwa w procesy zachodzące na rynku energii [Szczerbowski 2015, s. 10-11]. Priorytetami rządu stały się dywersyfikacja dostaw energii oraz zmniejszenie uzależnienia energetycznego kraju [Energy Security... 2012, Electricity Market... 2013]. Obecnie brytyjski miks energetyczny oparty jest w głównej mierze na paliwach kopalnych, co czyni podjęte działania szczególnie istotnymi. Udział energii pochodzącej z ropy naftowej i produktów ropopochodnych w miksie energetycznym kraju wynosi $36 \%$, gaz ziemny zaspokaja potrzeby kraju w 31\%, a węgiel w $16 \%$. Pojawiają się również obawy o wyeksploatowany majątek wytwórczy, co może zmniejszyć bezpieczeństwo energetyczne kraju. Zakłada się, że do 2020 r. jedna piąta elektrowni zostanie zamknięta, $\mathrm{z}$ tego dużą część nowych elektrowni będzie stanowiła tzw. generacja niestabilna (energetyka wiatrowa i fotowoltaika) lub nieelastyczna (energetyka jądrowa). Ponadto Wielka Brytania należy do liderów w rozwoju energetyki wiatrowej, szczególnie morskiej [Kaliski, Frączek i Szurlej 2011].

Podstawę systemu energetycznego Francji ma nadal stanowić energetyka jądrowa, co zostało potwierdzone w 2014 r. w najnowszych założeniach polityki energetycznej tego kraju. Założenia z 2012 r. zakładały stopniową redukcję bloków energetycznych opartych na paliwie jądrowym z ponad 73\% wytwarzanej energii elektrycznej do 50\% w 2025 r. Planuje się stopniowe zmniejszanie udziału energetyki jądrowej w miksie energetycznym kraju na rzecz energii pochodzącej z odnawialnych źródeł energii (rozbudowa elektrowni fotowoltaicznych i wiatrowych) [Szczerbowski 2015, s. 11].

W Danii przedstawiono założenia strategii energetycznej kraju, która zakłada zupełne odejście od paliw kopalnych do 2050 r. na rzecz zwiększania udziału 
energii pochodzącej ze źródeł odnawialnych, przede wszystkim z morskich farm wiatrowych. Jest to całkowicie nowatorskie podejście na świecie w kształtowaniu polityki energetycznej kraju. Planuje się, że do 2020 r. energia produkowana w Danii ma pochodzić w jednej trzeciej z odnawialnych źródeł energii. Natomiast do 2030 r. założono całkowite odejście od paliw kopalnych w produkcji energii elektrycznej [Szczerbowski 2015, s. 11].

Odmienne podejście do kształtu polityki energetycznej zaproponowano w Czechach. Zakłada się dalsze wykorzystywanie węgla, przede wszystkim brunatnego, przy jednoczesnym dalszym rozwoju energetyki jądrowej oraz dywersyfikacji pozostałych źródeł wytwarzania energii. Podstawowe założenia przedstawiono w 2011 r. W 2013 r. rozpoczęto proces wdrożenia długoterminowej strategii energetycznej z uwzględnieniem perspektywy do 2040 r. W 2014 r. elektrownie jądrowe stanowiły ok. $20 \%$ mocy zainstalowanej i odpowiadały za ponad $35 \%$ wytwarzanej energii elektrycznej. Planuje się, że energetyka jądrowa będzie odpowiadać za 49-58\% całkowitej produkcji energii elektrycznej w perspektywie do 2040 r. Ponadto udział węgla w produkcji energii elektrycznej powinien zostać obniżony z obecnego poziomu 38\% do ok. 20\% [Simplified Energy... 2016, Szczerbowski 2015, s. 11].

W 2015 r. przedstawiono założenia dokumentu Polityka energetyczna Polski do 2050 r., który zastąpił wcześniej obowiązujący dokument pn. Polityka energetyczna Polski do 2030 r. (http://www.me.gov.pl/Energetyka/Polityka+energetyczna, data dostępu: 22.10.2016). Zakłada się, że nadal podstawowym źródłem energii będą rodzime zasoby węgla kamiennego i brunatnego, co pozwoli na utrzymanie niezależności energetycznej kraju. Planuje się również włączenie energetyki jądrowej do miksu energetycznego Polski oraz dalszy rozwój sektora odnawialnych źródeł energii.

W 2016 r. rząd litewski przedstawił założenia nowej strategii energetycznej kraju, które częściowo korespondują z założeniami przedstawionymi w 2010 r. (uzyskanie energetycznej niezależności, wzmocnienie gospodarki kraju, rozwój odnawialnych źródeł energii) [Wyganowski 2010, s. 1]. Obecnie litewskie ministerstwo energii zakłada uzyskanie energetycznej niezależności dzięki realizacji projektu Nord Barlt2 do 2025 r. oraz połączenia z Polską - LitPol Link 2. Ponadto zadecydowano o odejściu od wykorzystania energetyki jądrowej w miksie energetycznym kraju i wstrzymaniu projektu budowy elektrowni jądrowej Visaginas ze względu na nieopłacalność ekonomiczną. W strategii wskazano także na konieczność przeprowadzenia badań na Morzu Bałtyckim w zakresie rozwoju morskich farm wiatrowych. Planuje się również, że do 2030 r. 35\% produkowanej na Litwie energii będzie pochodziło ze źródeł odnawialnych, a do 2050 r. poziom ten wzrośnie do 70\% [Nowa strategia... 2016]. 


\section{Zakończenie}

Kraje o stosunkowo niskim poziomie uzależnienia od importu surowców i energii (Czechy, Polska, Rumunia, Dania, Estonia) opierają swój bilans energetyczny na własnych naturalnych paliwach kopalnych lub na źródłach odnawialnych. W przypadku Polski udział paliw kopalnych w miksie energetycznym kraju wynosi 52\%. W przypadku Estonii jest to aż 66\%, a Czech 38\%. Udział paliw kopalnych w miksie energetycznym Rumunii wynosi 17\%, ale energia pochodząca ze źródeł odnawialnych odpowiada już za 19\% bilansu energetycznego tego kraju. W Danii natomiast dominuje energia pochodząca ze źródeł odnawialnych - 26\% w bilansie energetycznym kraju (dane za 2014 r. [Simplified Energy... 2016]).

Realizacja poszczególnych celów polityki klimatyczno-energetycznej Unii Europejskiej przebiega w wybranych krajach w różnym zakresie. Przeprowadzone badania pozwalają na wyciągnięcie wniosku, że coraz więcej państw prowadzi politykę energetyczną, opierając się przede wszystkim na polityce krajowej, która nie zawsze jest spójna z założeniami pakietu klimatyczno-energetycznego Unii Europejskiej.

Podstawową przeszkodą w pełnej realizacji wyznaczonych celów, obok kosztów nowych technologii, jest brak spójnych i efektywnych ram politycznych obejmujących swym zasięgiem całą Unię, a także brak stabilnej, długoterminowej wizji. Próbą rozwiązania tego problemu są nowe założenia pakietu klimatyczno-energetycznego przyjęte w 2014 r., wpisujące się również w postanowienia porozumienia międzynarodowego zawartego w Paryżu w 2015 r.

Należy także podkreślić, że wkład każdego państwa członkowskiego w osiągnięcie unijnych celów klimatyczno-energetycznych musi uwzględniać zróżnicowane warunki występujące w poszczególnych państwach członkowskich i różne punkty wyjścia, w tym udział energii z poszczególnych źródeł.

Przeprowadzone badania prowadzą ponadto do wniosku, że pomimo ustalenia oraz wdrożenia unijnej polityki klimatyczno-energetycznej, przyjęcia konkretnych jej celów oraz finansowego wsparcia ich realizacji, w wybranych do analizy państwach członkowskich realizacja tych celów przebiega z zachowaniem krajowego interesu w oparciu o krajową politykę energetyczną. Mając na uwadze zmiany zachodzące w Unii Europejskiej oraz w otoczeniu międzynarodowym należy przypuszczać, że w przyszłości w poszczególnych państwach będzie miała miejsce dalsza dywersyfikacja polityki energetycznej opartej na interesie krajowym, a nie na interesie całej Unii Europejskiej. Istnieje w związku z tym konieczność dokonania postępów w kierunku zapewnienia solidarności pomiędzy państwami członkowskimi, zwłaszcza w przypadku kryzysu energetycznego lub przerwy w dostawach energii. 


\section{Literatura}

Badera J., Kocoń P. [2014], Local Community Opinions Regarding the Socio-Environmental Aspects of Lignite Surface Mining: Experiences from Central Poland, „Energy Policy", vol. 66, https://doi.org/10.1016/j.enpol.2013.11.048.

Belyi A.V. [2016], Why Is the Oil Price Not about Equilibrium? An Economic Sociology Account of Petroleum Markets, „Energy Policy”, vol. 96, https://doi.org/10.1016/ j.enpol.2016.05.012.

Dena Ancillary Services Study 2030. Summary of the Key Results of the Study „Security and Reliability of a Power Supply with a High Percentage of Renewable Energy" by the Project Steering Group [2014], Deutsche Energie-Agentur GmbH (dena) - German Energy Agency, Berlin.

Electricity Market Reform [2013], Department of Energy and Climate Change, https:// www.gov.uk/ (data dostępu: 2.10.2016).

Energy Dependency [2016], Eurostat, http://ec.europa.eu/eurostat/tgm/table.do?tab=table\&init=1\&language $=$ en $\&$ pcode $=$ tsdcc310\&plugin $=1$ (data dostępu: 11.07.2016).

Energy Production and Imports [2016], Eurostat, http://ec.europa.eu/eurostat/statistics-explained/index.php/Energy_production_and_imports (data dostępu 15.09.2016).

Energy Security Strategy [2012], Department of Energy and Climate Change, https:// www.gov.uk/ (data dostępu: 2.10.2016).

Europejska polityka energetyczna [2007], Komisja Europejska, http://eur-lex.europa.eu/ legal-content/PL/TXT/PDF/?uri=CELEX:52007DC0001\&from=PL (data dostępu: 17.10.2016).

Final Energy Consumption [2016], Eurostat, http://ec.europa.eu/eurostat/tgm/table. do? tab $=$ table \&init $=1 \&$ language $=e n \&$ pcode $=$ t2020_34\&plugin $=1 \quad($ data dostępu: 15.09.2016).

Gołębiowski P., Klima G., Marciniak M., Parfieniuk P., Sowińska A. [2013], Model optymalnego miksu energetycznego dla Polski do roku 2060, Departament Analiz Strategicznych, Warszawa.

Greenhouse Gas Emissions [2016], Eurostat, http://ec.europa.eu/eurostat/tgm/refreshTableAction. do? $\mathrm{tab}=$ table $\&$ plugin $=1 \&$ pcode $=\mathrm{t} 2020 \_30 \&$ language $=\mathrm{en}($ data dostępu: 11.07.2016).

Gurgul H., Lach Ł. [2011], The Role of Coal Consumption in the Economic Growth of the Polish Economy in Transition, „Energy Policy”, vol. 39, https://doi.org/10.1016/ j.enpol.2011.01.052.

Kaliski M., Frączek P., Szurlej A. [2011], Brytyjskie doświadczenia a zmiana struktury źródet energii w Polsce, „Polityka Energetyczna - Energy Policy Journal”, t. 14, z. 2.

Kamiński J. [2010], Modelowanie systemów energetycznych - ogólna metodyka budowy modeli, „Polityka Energetyczna - Energy Policy Journal”, t. 13, z. 2.

Kasztelewicz Z. [2014], Doktryna energetyczna Polski na I połowe XXI wieku, „Polityka Energetyczna - Energy Policy Journal", t. 17, z. 3.

McCombie Ch., Jefferson M. [2016], Renewable and Nuclear Electricity: Comparison of Environmental Impacts, „Energy Policy”, vol. 96.

Nowa strategia energetyczna Litwy: Nadzieje na współprace Polski [2016], CIRE, http:// www.cire.pl/item,137282,1,0,0,0,0,0,nowa-strategia-energetyczna-litwy-nadzieje-na-wspolprace-polski.html (data dostępu: 18.10.2016). 
Odyssee-Mure [2015a], Energy Efficiency Country Profile: Czech Republic, http://www. odyssee-mure.eu/publications/profiles/czech-republic-efficiency-trends-policies-english.pdf (data dostępu: 11.08.2016).

Odyssee-Mure [2015b], Energy Efficiency Country Profile: Denmark, http://www. odyssee-mure.eu/publications/profiles/denmark-efficiency-trends-policies.pdf (data dostępu: 11.08.2016).

Odyssee-Mure [2015c], Energy Efficiency Country Profile: Germany, http://www. odyssee-mure.eu/publications/profiles/germany-efficiency-trends-policies.pdf (data dostępu: 11.08.2016).

Odyssee-Mure [2015d], Energy Efficiency Country Profile: Lithuania, http://www. odyssee-mure.eu/publications/profiles/lithuania-efficiency-trends.pdf (data dostępu: 11.08.2016).

Odyssee-Mure [2015e], Energy Efficiency Country Profile: Poland, http://www.odyssee-mure.eu/publications/profiles/ (data dostępu: 11.07.2016).

Odyssee-Mure [2015f], Energy Efficiency Country Profile: United Kingdom, http://www. odyssee-mure.eu/publications/profiles/united-kingdom-efficiency-trends-policies.pdf (data dostępu: 11.08.2016).

Odyssee-Mure [2015g], Energy Efficiency Trends and Policies in the EU, http://www. odyssee-mure.eu/publications/br/ (data dostępu: 11.07.2016).

Odyssee-Mure [2015h], Energy Efficiency Trends for Households in the EU, http://www. odyssee-mure.eu/publications/efficiency-by-sector/ (data dostępu: 11.07.2016).

Odyssee-Mure [2015i], Energy Efficiency Trends in Industry in the EU, http://www.odyssee-mure.eu/publications/efficiency-by-sector/ (data dostępu: 11.07.2016).

Odyssee-Mure [2015j], Energy Efficiency Trends in Transport in the EU, http://www. odyssee-mure.eu/publications/efficiency-by-sector/ (data dostępu: 11.07.2016).

Olkuski T. [2014], Udział gazu w strukturze produkcji energii elektrycznej w Wielkiej Brytanii w latach 2000-2012, ,Rynek Energii, nr 3.

Popławski T. [2012], Problematyka budowy modelu długoterminowej prognozy zapotrzebowania na energię elektrycznq dla Polski, „Polityka Energetyczna - Energy Policy Journal", t. 15, z. 3.

Primary Energy Consumption [2016], Eurostat, http://ec.europa.eu/eurostat/tgm/table. do?tab=table \&init $=1 \&$ language $=e n \& p c o d e=t 2020 \_33 \&$ plugin $=1 \quad($ data dostępu: 15.09.2016).

Riedel R. [2010], Supranationalisation of Energy Security in Europe. Theoretical Approaches, Centrum Europejskie Natolin, Warszawa, z. 40.

Share of Renewable Energy in Gross Final Energy Consumption [2016], Eurostat, http://ec.europa.eu/ eurostat/tgm/table.do?tab=table \&init=1\&language=en $\& \mathrm{p}-$ code=t2020_31\&plugin=1 (data dostępu: 11.07.2016).

Simplified Energy Balances [2016], Eurostat, http://ec.europa.eu/eurostat/web/energy/data/ energy-balances (data dostępu: 11.07.2016).

Szafrański A. [2014], Prawo energetyczne - wartości i instrumenty ich realizacji, C.H. Beck, Warszawa.

Szczerbowski R. [2015], Polityka energetyczna wybranych krajów europejskich a strategia energetyczna Polski, „Polityka energetyczna - Energy Policy Journal”, t. 18, z. 3.

Wyganowski J. [2010], Na Litwie: Nowa (stara) strategia, „Energia Gigawat”, nr 11. 


\section{Implementation of EU Climate and Energy Policy Goals in the Context of the Energy Policies of Chosen Member States}

(Abstract)

The main aim of this article is to present the results of the analysis of the EU climate and energy policy goals in selected Member States in the context of their energy policies. The analysis covers the period 2008-2014 and focuses on seven EU Member States: the Czech Republic, Denmark, Germany, France, Lithuania, Poland and the United Kingdom. Each of the countries is implementing EU climate and energy policy goals, but to varying degrees. The research leads to the conclusion that more and more countries implement energy policy primarily based on national policy, which is not always consistent with the assumptions of the EU's policy.

Keywords: climate and energy policy goals, energy efficiency, EU climate and energy policy, greenhouse gas emissions, renewable energy. 